\title{
Parasites of Columba livia (Aves: Columbiformes) IN TENERIFE (CANARY ISLANDS) AND THEIR ROLE IN THE CONSERVATION BIOLOGY OF THE LAUREL PIGEONS
}

\author{
FORONDA P.*, VALLADARES B.*, RIVERA-MEDINA J.A.*, FIGUERUELO E.*, ABREU N.* \& CASANOVA J.C.**
}

\section{Summary:}

The prevalence and intensity of the parasites from 50 wild doves (Columba livia) from the city of Santa Cruz de Tenerife, in the island of Tenerife (Canary Archipelago), were studied. The following ectoparasites were found in apparently healthy pigeons (prevalences are shown in percentage $(\%)$ and mean intensities with their standard deviations): the acari Dermanyssus gallinae (De Geer, 1778) (6 241.0 \pm 138.9) and Tinaminyssus melloi Fain, $1962(10 \%, 218.3 \pm 117.3)$; the louses, Columbicola columbae Linnaeus, $1758(100 \%, 111.4 \pm 76.8)$ and Campanulotes bidentatus Scopoli, 1763 (94\%, $48.4 \pm 26.6)$; and the pigeon fly, Pseudolynchia canariensis Macquart, 1839 $(36 \%, 6.2 \pm 1.6)$. The endoparasites we found, were: a haemoprotozoan species, Haemoproteus columbae Kruze, 1890 $(82 \%, 14.8 \pm 10.3$ per 1000); coccidian oocysts, Eimeria sp. $\left(50 \%, 0.2 \times 10^{3} \pm 1.7 \times 10^{3}\right.$ per grl); a cestode species Raillietina micracantha (Fuhrmann, 1909) López Neyra, 1947 $(44 \%, 12.3 \pm 9.4)$; and four nematode species, Tetrameres (Tetrameres) fissispina (Diesing, 1861) Travassos, 1915 (4\%, $99.5 \pm 34.1$ ), Synhimantus (Dispharynx) spiralis (Molin, 1858) $(8 \%, 46.8 \pm 11.6)$. Ascaridia columbae (Gmelin, 1790) Travassos, $1913(40 \%, 8.4 \pm 8.8)$ and Aonchotheca sp. $118 \%$, $6.0 \pm 3.11$. Several species detected in our study can be pathogens for $C$. bollii and $C$. junoniae, which are endemic pigeons of the Canary Islands, considered endangered species. Parasites (ectoparasites, protozoa and helminths) of C. livia found in Tenerife and others from wild and farm birds in the island were considered as healthy controls.

KEY WORDS : Columba livia, ectoparasites, helminths, protozoa, Tenerife.

\section{INTRODUCTION}

$\mathrm{P}$ igeons are a cosmopolitan group of birds with abundant and large populations associated, in most cases, with human activities. In the Canary

\footnotetext{
* Department of Parasitology, Ecology and Genetics, Faculty of Pharmacy, University of La Laguna, Avda. Astrofísico Fco. Sánchez s/n, 38203, Tenerife, Canary Islands, Spain.

** Laboratory of Parasitology, Faculty of Pharmacy, University of Barcelona, Avda. Diagonal s/n, 08028 Barcelona, Spain. Correspondence: Pilar Foronda Rodríguez.

Tel.: +0034922318484 - Fax: +0034922318514.

E-mail: pforonda@ull.es
}

Résumé : Parasites de COLUMba LIVIA (Aves : COlumbiformes) DF TÉNÉRIFE (Îles CANARIES) ET LEUR RÔle DANS LA BIOLOGIE DE LA CONSERVATION DES PIGEONS

Nous avons étudié la prévalence et l'intensité des parasites trouvés chez 50 pigeons sauvages (Columba livia). Il s'agissait de pigeons de Santa Cruz de Tenerife, capitale de lîle de Ténérife (îles Canaries). Nous avons représenté les prévalences en pourcentage (\%) et les intensités moyennes avec leurs déviations standard. Nous avons trouvé chez des pigeons apparemment en bonne santé les ectoparasites suivants : des acariens, Dermanyssus gallinae (De Geer, 1778) (6\%, 241,0 0 138,9) et Tinaminyssus melloi Fain, $1962(10 \%, 218,3 \pm 117,3)$; des poux, Columbicola columbae Linnaeus, $1758(100 \%, 111,4 \pm 76,8)$ et Campanulotes bidentatus Scopoli, $1763194 \%, 48,4 \pm$ 26,6): et la mouche du pigeon. Pseudolynchia canariensis Macquart, $1839(36 \%, 6,2 \pm 1,6)$. D'autre part, nous avons vu des endoparasites, à savoir, une espèce de hémaprotozoaire, Haemoproteus columbae Kruze, $1890182 \%, 14,8 \pm 10,3$ pour 10001; des oocystes de coccidies, Eimeria sp. $150 \%, 0,2 \times$ $103 \pm 1,7 \times 103$ dans $1 \mathrm{gr})$; une espèce de cestode Raillietina micracantha (Fuhrmann, 1909) López Neyra, 1947 144\%, $12,3 \pm 9,4)$; et quatre espèces de nématodes, Tetrameres (Tetrameres) fissispina (Diesing, 1861) Travassos, 1915 14\%, 99,5 $\pm 34,11$, Synhimantus (Dispharynx) spiralis (Molin, 1858) $(8 \%, 46,8 \pm 11,6)$. Ascaridia columbae (Gmelin, 1790) Travassos, $1913(40 \%, 8,4 \pm 8,8)$ et Aonchotheca sp. $118 \%$, $6,0 \pm 3,11$. Quelques-unes des espèces étudiées peuvent être pathogènes pour $C$. bollii et $C$. junoniae, lesquelles sont des pigeons endémiques des Illes Canaries, et sont considérées en voie de disparition. Les parasites de C. livia de l'île de Ténérife (ectoparasites, protozoaires et helminthes) et d'autres trouvés dans des oiseaux sauvages et domestiques de la même ile peuvent être considérés comme des indicateurs de l'état de santé.

MOTS CLÉS : Columba livia, ectoperasite, helminthe, protozoaire, Ténérife.

Islands, three species of the genus Columba are described, the rock dove, C. livia, the dark-tailed laurel pigeon, C. bollii, and the white-tailed laurel pigeon, C. junioniae. The presence of other species such as the stock dove (C. oenas) and the woodpigeon (C.palumbus) is accidental or irregular and they have been observed in the migration station. Columba bollii and C. junioniae are endemic species of the Canary Islands. Both are representatives of a characteristic habitat of the Canaries called laurel forest, the forest type with the highest plant diversity of these islands. Columba bollii and C. junoniae were considered in endangered species at the Bonn Convention 1979 on the protec- 
tion and conservation of bird species. The most common species of pigeon in the Canary Islands is C. livia which inhabits in forests, cities and villages. Whereas C. livia is considered abundant in Tenerife, only 350-400 individuals of $C$. bollii and 80-120 individuals of C.junionae are present in this island (Emmerson, 1985).

The parasitic fauna (arthropoda, protozoa and helminths) of C. livia in Europe, Asia, Africa and America is well known. Several helminth parasites decrease host survival and breeding success, and consequently, they can affect the population dynamics of their hosts (Hudson et al., 1992). Helminths of C. livia may affect host fitness by increasing morbidity and predation risk as well as reducing clutch size, weakening body condition or altering metabolic rates (Hudson \& Dobson, 1995).

In 2001, the canary government allowed the capture of several individuals of C. livia in the city of Santa Cruz de Tenerife, located near the laurel forest, in order to study the parasitic infections of these hosts. The aim of this study was to identify the potential risk of parasitic transmission between $C$. livia and the other two endemic and protected pigeon species ( $C$. bollii and C. junionae) in Tenerife.

\section{MATERIAL AND METHODS}

he Canary Archipelago is located between $13^{\circ}$ $23^{\prime}$ to $18^{\circ} 8^{\prime} \mathrm{W}$ and $27^{\circ} 37^{\prime}$ to $29^{\circ} 24^{\prime} \mathrm{N}$ in Macaronesia along with the islands of Madeira, Azores, Savages and Cape Verde. Tenerife is the largest island of the archipelago. For this study, pigeons were captured throughout the year 2001 in Tenerife.

In the captured birds, plumages were examined for ectoparasites and the nasal passages were examined for nasal mites using a magnifying glass. The ectoparasites were collected with tweezers and preserved in $70^{\circ}$ ethanol for taxonomic identification.

Blood samples were obtained from each animal and blood smears were performed, air-dried, fixed in methanol and stained with Giemsa's solution. The slides were examined under light microsocope at a magnification of $100 \mathrm{x}$. Parasitized and unparasitized cells were counted to estimate the parasite intensity. Hosts were dissected and their digestive tracts, lungs and livers were examined for helminths. Cestode and nematode species were recovered and preserved in $70 \%$ ethanol. Platyhelminths were stained with Semmichon acetocarmine, dehydrated sequentially in alcohol, cleared in xylol, and mounted in Canada balsam. Nematodes were cleared in Amann lactophenol. Faecal samples were collected from the rectum of all dissected pigeons, stored in $2.5 \%(\mathrm{w} / \mathrm{v})$ potassium dichromate solution $\left(\mathrm{Kr}_{2} \mathrm{Cr}_{2} \mathrm{O}_{7}\right)$, maintained at room temperature $\left(23-28^{\circ} \mathrm{C}\right)$ for the coccidia sporulation and examined microscopically after flotation using saturated saline solution. Oocysts of coccidia were counted in a $1 \mathrm{~g}$ sample of feaces using the McMaster technique.

Several specimens of four nematode species were prepared for Scanning Electronic Microscopy (SEM) study following the general methodology described in the literature (Miquel et al., 1995). The specimens were examined with an electron microscope (Hitachi S-2300). Statistical $\chi^{2}$ and ANOVA tests were used to determine differences in the prevalences and mean intensities of parasites between males and females of C. livia and between seasons (Bush et al., 1997). Species counts were $\log$ transformed to normalize the distribution.

\section{RESULTS}

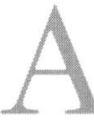
total of fifty pigeons were examined. Five ectoparasite species were recovered and representative specimens were deposited at the Natural History Museum of Tenerife: Tinaminyssus melloi Fain, 1962, (accession no. TFMC/AC-18) Dermanyssus gallinae (De Geer, 1778) (TFMC/AC-17) (Dermanyssidae) [Acari]; Campanulotes bidentatus Scopoli, 1763, (TFMC/ ML-16) Columbicola columbae Linnaeus, 1758 (TFMC/ ML-15) (Phylopteridae) [Mallophaga]; and Pseudolynchia canariensis Macquart, 1839 (TFMC/DI-387) (Hippoboscidae) [Diptera]. The ectoparasite species were collected from the plumage of the hosts except for $T$. mello $i$ which was recovered from the nasal passages. The mallophaga were found with high prevalences, C. columbae was present in all the examined pigeons and C. bidentatus in $94 \%$ of the doves, with a mean intensity and a standard deviation of $111.4 \pm 76.8$ and $48.4 \pm 26.6$, respectively. Pseudolynchia canariensis was found in 18 hosts $(36 \%)$ with a mean intensity of $6.2 \pm 1.6$. Tinaminyssus mello $i$ and D. gallinae was found with lower prevalences (10\% and $6 \%$, respectively) but with high mean intensities, $218.3 \pm 117.3$ for T. mello $i$ and $241.0 \pm 138.9$ for $D$. gallinae.

Two species of protozoa were found: Haemoproteus columbae Kruze, 1890 (Haemoproteidae) in $82 \%$ of the examined animals, with a mean intensity of $14.8 \pm$ 10.3 infected cells per 1,000 red blood cells, and Eimeria spp. (Eimeriidae) in the faeces of $50 \%$ of the doves with a mean of $0.2 \times 10^{3} \pm 1.7 \times 10^{3}$ per gr.

Helminth species recovered from the parasitized doves were deposited in the Natural History Museum of Tenerife: Raillietina micracantha (Fuhrmann, 1909) López Neyra, 1942 (accesion no. TFMCCS/0006) (Davaineidae) [Cestoda], Tetrameres (Tetrameres) fissispina (Diesing, 1861) Travassos, 1915 (TFMCNA/0006) (Tetrame- 
ridae), Synhimantus (Dispharynx) spiralis (Molin, 1858) (TFMCNA/0007) (Acuariidae), Ascaridia columbae (Gmelin, 1790) Travassos, 1913 (TFMCNA/0008) (Ascaridiidae) and Aonchotheca sp. (TFMCNA/0009) (Trichuridae) [Nematoda]. Raillietina micracantha was first described by López Neyra (1947) and Joyeux \& Baer (1936). Only males of T. (T.) fissispina were found whereas individuals of both sexes were recovered from $S$. (D.) spiralis and A. columbae. Species identification of these nematodes was carried out by metrical measurements and SEM studies.

Raillietina micracantha, was presented with a prevalence of $44 \%$ and a mean intensity and standard deviation of $12.3 \pm 9.4$. The most prevalent nematode was $A$. Columbae which was found in $40 \%$ of the studied hosts with a mean intensity of $8.4 \pm 8.8$, followed by Aonchotheca sp. (18\%, $6.0 \pm 3.1)$. The oesophagial nematodes appeared in a lower number of the doves, with prevalences and mean intensities of $8 \%$ and $46.8 \pm 11.6$ in S. (D.) spiralis, and $4 \%$ and $99.5 \pm$ 34.1 in $T$. (T.) fissispina.

No significant differences in the prevalences and mean intensities of the parasites were found between host sexes. The parasite species were found in all seasons with NS seasonal differences in the prevalences and mean intensities for any species.

\section{DISCUSSION}

E ctoparasite species found in our study are commonly cited in Columbiformes and specifically $\checkmark$ in C. livia. Campanulotes bidentatus has been recovered from several Columba species (Cordero del Campillo et al., 1994). Columbicola columbae infects different families of birds, for example Turdidae and Accipitridae (Cordero del Campillo et al., 1994). Tinaminyssus mello $i$ is a cosmopolitan species of domestic pigeons (Pence, 1973) and has been reported at another related genera of hosts, such as Streptopelia (Cordero del Campillo et al., 1994). Dermanyssus gallinae (De Geer), the cosmopolitan poultry red mite or chicken mite, is an economically important ectoparasite of domesticated fowl (Kettle, 1993). It may become a serious pest, causing irritation and anemia and in some cases even death of its host (Kirkwod, 1967). Dermanyssus gallinae feeds on the blood of domestic fowl, caged birds and pigeons as well as wild birds (McGarry \& Trees, 1991), and it may eventually attack mammals (Ducan, 1957; Hoffman, 1987).

It is interesting to realize that in the low number of examined hosts, the presence of $P$. canariensis and $H$. columbae has considered usual. The pigeon fly, $P$. canariensis, is the intermediate host of this haemoproteid which lives in the nest of the pigeon (Garnham,
1966), and it was incriminated as the vector of H. columbae in natural (Klei \& de Giust, 1975) and experimental infection (Ahmed \& Mohammed, 1977). Haemoproteus columbae is the only haemoparasite found in blood smears of the doves examined. It is a common and cosmopolitan parasite of the domestic pigeon in most parts of the world (Garnham, 1966), and it has been found in different species of wild doves of the genera Zenaida, Columbina and Scardafell (Adriano \& Cordeiro, 2001), although it is not considered pathogenic. The high prevalence may involve behavioral aspects or some physiological condition within the species (White et al., 1978). From a behavioural point of view, C. livia inhabits in Tenerife in large flocks which eases the transmission of vectors and leads to a high prevalence and intensity of parasites.

Eimeria is probably one of the most frequent genera of coccidia in nature (del Cacho et al., 1999). Eimeria spp. from pigeons are clearly considered pathogens with a morbidity in young individuals that could rise up to $15-70 \%$ but it is not a pathogen in mature doves (Cordero del Campillo \& Hidalgo Argüello, 1999).

Besides C. livia, only two other species of this genus are examined for helminths, C. inornata and C. oenas. In both of them, only one species was found, Tanaisia bragai dos Santos, 1934 in Puerto Rico (Arnizaut et al., 1992) from C. innornata and Raillietina echinobothrida (Megnin, 1880) from C. oenas in Spain (Cordero del Campillo et al., 1994). Rock doves from Tenerife harboured a helminth community relatively poor in species if it is compared to many other populations of pigeons of this species. For C. livia, a total of 47 helminth species have been cited in the world.

Three species of digenean trematodes [Brachylaima columbae Mazzanti, 1899, Brachylaima fuscata Rudolphi, 1819 and Echinoparyphium recurvatum (Linstow, 1873) Luhe, 1909] were found in C. livia from Europe (Catelli et al., 1999; Cordero del Campillo et al., 1994; Kulisic, 1988; Martínez-Moreno et al., 1989). No digeneans were found in our study. In the prospected urban area, terrestrial and aquatic snails seemed to be unimportant in the diet of C. livia, but in the laurel forest, with a high diversity and abundance of terrestrial snails, it could be possible that C. bollii and C. junoniae include these potential intermediate hosts of brachylaimid trematodes (Pojmanska, 2001), in their diets. Davained cestodes, mostly from the genus Raillietina Schmidt (1986) or Raillietina, Skrjabinia and Furbmannetta (Jones \& Bray, 1994) are dominant species in the fauna of plathyhelminthes against anoplocephalids and hymenolepidids (Foronda, 2002). Only one species, $R$. micracantha, has been previosly cited in the Canary Islands parasitizing C. livia (Gijón Botella et al., 1989). 
The African mainland is near the Canary Islands (only $100 \mathrm{~km}$ away). Individuals of C. livia could originally be from Africa but no genetic data on the Canarian and African populations are available. In view of our results, it is difficult to confirm the hypothesis of an interelation between Africa and the Canaries from the helminthological point of view. As in Tenerife, no digeneans were cited in C. livia from Africa. The species of the genus Raillietina are not good indicators of the geographical origin of C. livia in the Canary Islands, because African species of this genus parasitizing rock doves have not been named (Mushi et al., 2000). Cotugnia digonopora (Davaineidae) is presented in African and Asian pigeons (Ibrahim et al., 1995; Patel et al., 2000) but it is absent in Tenerife. We compared the helminth fauna of C. livia in Tenerife with that of Iberian Peninsula, from the same host, because the human introduction of C. livia from Iberia into the Canaries is well known. All the species found in the rock dove in Tenerife were previously denounced in the Iberian Peninsula but they seem to be poor geographic indicators. The endemic cestode species found in Spanish doves, Hymenolepis cordobensis Jordano, 1952 was not found in Tenerife. From the rest of cestodes cited in the Iberian Peninsula in C. livia (Choanotaenia infundibulum, Killigrewia delafondi, Paradicranotaenia anormalis, R. echinobothrida, R. joyeuxi, R. micracantha, Furbmannetta pluriuncinata, Skrjabinia bonini, Sobolevicanthus columbae) (Cordero del Campillo et al., 1994), only $R$. micracantha seems to have possibly been introduced from spain into the Canary Islands, but this species is widely distributed in this host in Europe (Foronda, 2002) and it is not an specific parasite, for it has been obtained from several genera of birds (Turdus, Columba and Stigmatopoelia) (Schmidt, 1986). The species, C. infundibulum Bloch, 1779 cited in C. livia in Spain (Cordero del Campillo et al., 1994) was found in Tenerife parasitizing Alectoris barbara (Phasianidae) [Foronda, 2002, Foronda "unpublished data" (GeneBank accession no AJ555171AJ555172)]. As well as in C. livia, the presence in Tenerife of introducted farm specimens of Alectoris sp., from the Iberian Peninsula, could explain the introduction of $C$. infundibulum in the Canary Islands.

Paleartic cestodes of $C$. livia which have been not cited in the Iberian Peninsula for this host, includes the davaineid, Davainea proglottina from Serbia (Kulisic et al., 1996) and $R$. tetragona from Greece (Githkopoulos \& Liakos, 1987), Italy (Tacconi et al., 1993) and Serbia (Kulisic et al., 1996). However they were reported in Iberia in other hosts, D. proglottina was found in chickens, and R. tetragona in chickens, Alectoris rufa and Meleagridis gallopavo (Cordero del Campillo et al., 1994).

The nematode fauna of C. livia in Tenerife includes only a habronematoid, an acuarioid, an ascarid and a thrichurid species. Tetrameres fissispina was identified by SEM. This species has a wide range of distribution parasitizing farm birds. Moreover, other wild bird species such as Larus larus and Tardona tardona have been cited as hosts of this nematode. From the north to the south of Spain, this species is widely distributed in diverse bird species (Cordero del Campillo et al., 1994). Synhimantus spiralis is present in all biogeographical regions parasitizing Galliormes, Columbiformes and Passeriformes (Hwang et al., 1691). The low specificity of this nematodes for the definitive hosts and the high apparent adaptation of their life cycle in Tenerife could be an important risk for $C$. bollii and C. junionae because both, T. fissispina and D. spiralis, are often capable of causing the death of infected animals (Tarazona Vilas, 1999).

Ascaridia columbae is a typical parasite of Columba spp. with a cosmopolitan distribution (Foronda, 2002) that can also affect other genera, such as Zenaida (Barus \& Herrera Rodríguez, 1969). This parasite causes weight loss and diarrhoea in heavy infections similar to capillariosis in the parasitized birds (Tarazona Vilas, 1999).

The dark-tailed laurel pigeon and the white-tailed laurel pigeon are endemic to the Canary Islands. Columba bollii is classified as Rare by IUCN (Groombridge, 1993) and considered Vulnerable at world level (Collar et al., 1994). Columba junoniae is classified as Vulnerable at global and European levels (Collar et al., 1994) and it is classified as Rare by IUCN (Groombridge, 1993). Both species were also listed in Annex I of the EU Wild Birds Directive and the Appendix II of the Bern Convention. The diet of both pigeons consists mainly of fruit (Emmerson, 1985). In C. bolli besides fruit, the birds feed on leaves, shoots, and leaf and flower buds, and they may, if the opportunity arises, supplement their diet with small invertebrates (Emmerson, 1985).

Only one important viral disease, the Newcastle, is considered dangerous for C. bollii and C. junoniae (Action Plan for the dark-tailed laurel pigeon, and Action Plan for the white-tailed laurel pigeon, SEO/BirdLife International, Tenerife) due to the absence of data from other parasitic diseases. Our faunistical study of C. livia in Tenerife shows that parasite diseases (arthropods, protozoa and helminths) could produce dangerous diseases in the endemic dove populations in Tenerife. Parasites detected in C. livia in Tenerife are considered generally as species with a low degree of specificity due to the fact that they are able to establish in different species of Columbiformes and other hosts with a wide range of distribution in the world, therefore it is reasonable to consider them as threats to the endangered species. In the view of the C. livia parasites that were found in native and introduced bird species in Tenerife (Foronda, 2002) we consider that an increase 
in the frequency of health controls on wild and farm birds in the Canary Islands would be highly recommendable.

\section{ACKNOWLEDGEMENTS}

W e wish to thank the "Excelentísimo Ayuntamiento de Santa Cruz de Tenerife" and 2001SGR00088 project by the "Comissionat por la Recerca y Universitats de la Generalitat de Catalunya (Catalonia Government)" for supporting this study.

\section{REFERENCES}

Adriano E.A. \& Cordeiro N.S. Prevalence and intensity of Haemoproteus columbae in three species of wild doves from Brazil. Memórias do Instituto Oswaldo Cruz, 2001, 96, $175-178$.

Ahmed F.E. \& Mohammed A.H. Schizogony in Haemoproteus columbae Kruse. Journal of Protozoology, 1977, 24, 389393.

Arnizaut A.B., Hayes L., Olsen G.H., Torres J.S., Ruiz C. \& PÉREz-RIVERA R. An epizootic of Tanaisia bragai in a captive population of Puerto Rican plain pigeon (Columba inomata wetmorei). Annals of the New York Academy of Sciences, 1992, 653, 202-205.

Barus V. \& Herrera-Rodríguez R. Sobre la presencia del nematodo Eucolueus annulatus (Molin, 1858) en Cuba. Serie Monográfica del Instituto Nacional de Medicina Veterinaria, Habana, 1969, 9, 3-7.

Bush A.O., Lafferty K.D., Lotz J.M. \& Shostak A.W. Parasitology meets ecology on its own terms: Margolis et al. revisited. Journal of Parasitology, 1997, 83, 575-583.

Catell E., Poglayen G., Terregino C., Orlando C., Tonelli A., Issa Gadale O., Roda R. \& Agnoletti A. Indagine sui parassiti dellapparato diferente di Columba livia (Gmelin 1789) nella città di Firenze. Selezione Veterinaria, 1999, 2, 75-85.

Collar N.J., Crosby M.J. \& Stattersfield A.J. Birds to watch 2: the world list of threatened birds. Cambridge UK: BirdLife International (BirdLife Conservation Series n 4), 1994

Cordero del Campillo M., Castañon-Ordoñez l. \& Reglera FEO A. Índice-catálogo de zooparásitos ibéricos, $2^{\text {nd }}$ ed., Secretariado de Publicaciones, Universidad de León, León, 1994, $650 \mathrm{pp}$.

Cordero del Campillo M. \& Hidalgo Argüello R. Otras coccidiosis aviares, in: Parasitología Veterinaria. Cordero del Campillo et al. (eds), McGraw-Hill-Interamericana de España, Madrid, 1999, 768-770.

del Cacho E., Sierra M.A. \& Sánchez-Acedo C. Coccidiosis aviar (Eimeriosis), in: Parasitología Veterinaria. Cordero del Campillo et al. (eds), McGraw-Hill-Interamericana de España, Madrid, 1999, 757-768.

Duncax S. Dermanyssus gallinae (De Geer, 1778) attacking man. Journal of Parasitology, 1957, 43, 637.
Emmerson K.W. Estudio de la biología y ecología de la Paloma Turqué y la Paloma Rabiche con vistas a su conservación, 1 and 2. Tenerife: Ornistudio S.L., 1985.

Foronda P. Estudio faunístico y sistemático de helmintos de aves de Canarias. Ph. Thesis, La Laguna, Universidad de La Laguna, 2002.

GARnham P.C.C. Malaria parasites and other Haemosporidia. Blackewll Scientific Publications, Oxford, UK, 1966.

Gijón-Botella H., del Castillo-Remiro J.A. \& López-Román R. Estudio al M.E.B. de Raillietina (Raillietina) micracantha Fuhrmann 1908 parásito de Columba livia domestica capturadas en las Islas Canarias. Revista Ibérica de Parasitologia, 1989, 49, 37-40.

Githkopoulos P.R. \& Liakos V.D. Parasites of the alimentary tract of pigeons in Greece. Deltion tes Ellenikes Kteniatrikes Etaireias, 1987, 38, 79-83.

Groombridge B. (ed.) 1994 IUCN Red List of threatened animals. IUCN Gland, Switzerland and Cambridge, UK: International Union for Conservation of Nature and Natural Resources, 1993.

Hoffman G.V. Vogelmilben als Lästlinge, Kranken-heitsserzeuger und Vektoren bei Mensch und Nutztier (Veterinary and hygienic importance of the red chichen mite and the northern fowl mite). Deutschen Tierarztliche Wochenschrift, 1987, 95, 7-10.

Hudson P.J. \& Dobson A.P. Macroparasites: observed patterns in naturally fluctuating animal populations, in: Ecology of infections diseases in natural populations. Grenfell B.T. \& Dobson A.P. (eds), Cambridge University Press, Cambridge, 1995, 144-176.

Hudson P.J., Newborn D. \& Dobson A.P. Regulation and stability of free-living host-parasite system, Trichostrongylus temuis in red grouse. Monitoring and parasite reduction experiments. The Journal of Animal Ecology, 1992, 61, 477486.

Hwang J.G., Tolgay N., Shalkop W.T. \& Jaquette D.S. Case report Dispharynx nasuta causing severe proventriculitis in pigeon. Avian Diseases, 1961, 5, 60-65.

Ibrahim A.I., Hassann H.H., Aly S.E.M. \& Abdel Aal A.A. A study on some parasitic affections in domestic pigeons in Ismalia province. Assiut Veterinary Medical Journal, 1995 , 34, 153-161.

Jones A. \& BRAY R.A. Family Davaineidae Braun 1900, in: Keys to the cestode parasites of vertebrates. Khalil L.F., Jones A. \& Bray R.A. (eds), CAB International, Walling Ford, Oxon, UK, 1994, 407-441.

Joyeux C. \& Baer J.G. Cestodes, in: Faune de la France Paul Lechevalier et Fils, Paris, 1936, 613.

KettLe D.S. Ascari-Prostigmata and Gamasidae. In: Medical and veterinary entomology, $1^{\text {st }}$ ed., CAB, Wallingford, UK. 1993, 380-405.

Kirkwood A.C. Anemia in poultry infested with red mite Dermanyssus galinae. Veterinary Record, 1967, 80, 514-516.

KLeI T.S. \& DE Giusti D.L. Seasonal occurrence of Haemoproteus columbae Kruse and its vector Pseodolynchia canariensis Bequaert. Journal of Wildlife Diseases 1975, 11, $130-135$. 
Kulisic Z. Endoparasite fauna of pigeons (Columba livia) as detected in the city of Belgrade. Acta Veterinaria, 1988, $38,37-42$.

Kulisic Z., Pavlovic I. \& Milutinovic M. Contribution to knowledge of parasitofauna of pigeons in Belgrade from 1990-1994. Veterinarski Glasnik, 1996, 50, 785-790.

López NeYra C.R. Helmintos de los vertebrados ibéricos. CSIC, Instituto Nacional de Parasitología de Granada, Granada, 1947.

Martín Mateo M. P. Revisión de malofagos Philopteridae denunciados en España como parásitos de aves demésticas. Revista Ibérica de Parasitologia 1975, 35 (1-2), 41-68.

Martínez-Moreno F.J., Martínez-Moreno A., Becerra-Martell C. \& Martínez-Cruz M.S. Parasitofauna of pigeon Columba livia in the province of Cordoba Spain. Revista Ibérica de Parasitologia, 1989, 49, 279-282.

McGarky J.W. \& TReEs A.J. Trap perches to assess the activity of pyrethrins against poultry red mite Dermanyssus gallinae in cage birds. Experimental Applied Acarology 1991, 12, 1-7.

Miguel J., Casanova J.C., Tenora F., Feliu C. \& Torres J. A scanning electron microscope study of some Rictulariidae (Nematoda) parasites of Iberian mammals. Helminthologia 1995, 32, 3-14.

Mushi E.Z., Binta M.G., Chabo R.G., Ndebele R. \& Panzirah R. Parasites of domestic pigeons (Columba livia domestica) in Sebele, Gaborone, Botswana. Journal of the South African Veterinary Association, 2000, 71, 249-250.

Patel P.V., Patel A.I., Sahu R..K. \& Raju V. Prevalence of gastrointestinal parasites in captive birds of Gujarat zoos. Zoos' Print Journal, 2000, 15, 295-296.

Pence D.B. The nasal mites of birds from Louisana. IX. Synopsis. The Journal of Parasitology. 1973, 59, 881-892.

PojManska T. Family Brachylaimidae Joyeux and Foley 1930, in: Keys to the Trematoda, Gibson D.I., Jones A. \& Bray R.A. (ed.), CAB International, Walling Ford, Oxon, UK, Vol. I, 2001, 37-43.

Schmidt G.D. CRC handbook of tapeworm identification. Boca Raton, Florida: CRC Press, 1986, 675.

Tacconi G., Moretti A., Piergili Fioretti D. \& Latini M. Endoparasitosi del colombo torraiolo (Columba livia Gmelin 1789, forma urbana):rilievi epidemiologici nella citta di Terni. Zootecnia Internacional, 1993, 4, 83-85.

Tarazona Vilas J.M. Nematodosis, in: Cordero del Campillo et al. Parasitología Veterinaria, McGraw-Hill-Interamericana de Espana, Madrid, 1999, 791-808.

White E.M., Greiner E.C., Bennet G.F. \& Herman C.M. Distribution of the hematozoa of Neotropical birds. Revista de Biología Tropical, 1978, 26, 43-102.

Reçu le 20 novembre 2003 Accepté le $1^{\text {er }}$ avril 2004 